\title{
Supervision of Community Health Agents in the Family Health Strategy: the perspective of nurses*
}

\author{
SUPERVISÃO DOS AGENTES COMUNITÁRIOS DE SAÚDE NA ESTRATÉGIA SAÚDE DA \\ FAMÍLIA: A ÓTICA DOS ENFERMEIROS
}

\author{
SUPERVISIÓN DE LOS AGENTES COMUNITARIOS DE SALUD EN LA ESTRATEGIA \\ SALUD DE LA FAMILIA: LA ÓPTICA DE LOS ENFERMEROS
}

\section{Juliana Sterci da Silva1, Cinira Magali Fortuna², Maria José Bistafa Pereira ${ }^{3}$, Silvia Matumoto², Fabiana Ribeiro Santana ${ }^{4}$, Franciele Maia Marciano ${ }^{1}$, Jael Bernardes Silva ${ }^{5}$, Marianna Ferreira ${ }^{5}$, Silvana Martins Mishima ${ }^{6}$}

\begin{abstract}
Objective: Analyzing the conceptions of supervision of nurses in the Family Health Strategy (ESF - Estratégia Saúde da Família) in relation to community health workers (ACS - Agente Comunitário de Saúde), taking for reference the work process and the power relations. Method: A qualitative study, in which 18 interviews were carried out with nurses from the ESF in the countryside of the state of Goiás. Following transcription, the data were subjected to thematic content analysis and the following categories were identified: Supervision with that sees it all and Supervision is participating and working together. Results: Among the findings, it is clear the character of control and monitoring that is carried out primarily through printed instruments and home visits, which constitute vertical and impositive relations, and suffer influence of the local health management. Another finding is the supervision as acting together and with the educational perspective. Conclusion: The supervision carried out does not provide the changes intended by the ESF.
\end{abstract}

\section{DESCRIPTORS}

Nursing Supervisory

Family Health Strategy

Community Health Workers

Primary Health Care

\begin{abstract}
RESUMO
Objetivo: Analisar as concepções de supervisão de enfermeiros na Estratégia Saúde da Família (ESF) em relação aos Agentes Comunitários de Saúde, tendo por referencial o processo de trabalho e as relações de poder. Método: Estudo qualitativo, no qual foram realizadas 18 entrevistas com enfermeiros da ESF do interior do estado de Goiás. Após a transcrição, os dados foram submetidos a análise de conteúdo temática, sendo identificadas as seguintes categorias: Supervisão de olho em tudo e Supervisão é participar e trabalhar juntos. Resultados: Dentre os achados, é evidente o caráter de controle e fiscalização realizados, principalmente, por meio de instrumentos impressos e visitas domiciliares, constituindo relações verticalizadas e impositivas e sofrendo a influência da gestão de saúde local. Outro achado é a realização da supervisão como um fazer junto e com a perspectiva educativa. Conclusão: A supervisão realizada não proporciona as mudanças pretendidas pela ESF.
\end{abstract}

\section{DESCRITORES}

Supervisão de Enfermagem

Estratégia Saúde da Família

Agentes Comunitários de Saúde

Atenção Primária à Saúde

\begin{abstract}
RESUMEN
Objetivo: Analizar las concepciones de supervisión de enfermeros en la Estrategia Salud de la Familia (ESF) con relación a los Agentes Comunitarios de Salud, teniendo como referencia el proceso laboral y las relaciones de poder. Método: Estudio cualitativo, en el que se llevaron a cabo 18 entrevistas con enfermeros de la ESF del interior del Estado de Goiás. Luego de la transcripción, los datos fueron sometidos a un análisis de contenido temático, siendo identificadas las seguientes categorías: Supervisión no quitar el ojo y Supervisión es participar y trabajar juntos. Resultados: Entre los hallazgos, es evidente el carácter de control y fiscali-zación realizados, especialmente mediante instrumentos impresos y visitas domiciliarias, constituyéndose relaciones verticalizadas e impositivas y sufriendo la influencia de la gestión de salud local. Otro hallazgo es la puesta en marcha de la supervisión como un acto conjunto y con perspectiva educativa. Conclusión: La supervisión llevada a cabo no proporciona los cambios pretendidos por la ESF.
\end{abstract}

\section{DESCRIPTORES}

Supervisión de Enfermeira Estrategia de Salud Familiar Agentes Comunitarios de Salud Atención Primaria de Salud

\footnotetext{
* Extracted from the dissertation "O processo de trabalho do enfermeiro na supervisão ao Agente Comunitário de Saúde em equipes de saúde da família", School of Nursing of Ribeirão Preto, Universidade de São Paulo, 2014. ${ }^{1}$ MSc at the Post-Graduate Program in Public Health Nursing, School of Nursing of Ribeirão Preto, Universidade de São Paulo, Ribeirão Preto, SP, Brazil. ${ }^{2}$ Professor, School of Nursing of Ribeirão Preto, Universidade de São Paulo, Ribeirão Preto, SP, Brazil. ${ }^{3}$ Full Professor, School of Nursing of Ribeirão Preto, Universidade de São Paulo, Ribeirão Preto, SP, Brazil. ${ }^{4}$ Assistant Professor, Nursing Course, Universidade Federal de Goiás, Campus Catalão, GO, Brazil. ${ }^{5}$ Doctorate Student, Post-Graduate Program in Public Health Nursing, School of Nursing of Ribeirão Preto, Universidade de São Paulo, Ribeirão Preto, SP, Brazil. ${ }^{6}$ Professor, Department of Maternal-Infant Nursing and Public Health, School of Nursing of Ribeirão Preto, Universidade de São Paulo, Ribeirão Preto, SP, Brazil.
} 


\section{INTRODUCTION}

The supervision in the healthcare sector presents several concepts, such as the following: evaluation process, teaching, disciplining and identifying problems ${ }^{(1)}$, educational and control character, political articulation ${ }^{(1-3)}$, as well as support, self-analysis and self-management coordination $^{(2)}$.

In nursing, the supervision can be useful to reproduce the work control of other categories, in view of the technical and social division of labor. On the other hand, it can be an instrument to rethink work, and favor care and management activities related to the development of skills and competencies of the health care team ${ }^{(4-6)}$.

In this study we considered nursing as a social practice ${ }^{(7)}$, since it is historically formed in social relations and connected to the production mode of society. It is articulated with other social practices such as health and education, and can be understood from theoretical frameworks of anthropology and sociology, among others.

The work of nurses can be developed in different environments such as hospitals, companies, households, basic health units, family health units, among others.

The Family Health Strategy (ESF - Estratégia Saúde da Família) is one of the working areas of nurses. It is characterized as the form adopted for reorganization of primary health care services in Brazil, consisting of a multidisciplinary team responsible for the population residing in a delimited territory. The strategy has families as the focus of care, and is considered an innovative proposal in health care.

In primary care, especially in the ESF, the supervision of Community Health Agents (ACS - Agentes Comunitários da Saúde) has been done by nurses, who are one of the closest workers to their daily lives. In theory, the supervision could be done by other professionals in the ESF, and according to the present legislation ${ }^{(8)}$, this duty is not explicitly assigned to nurses.

For the purposes of this work, the supervision will be considered an instrument of the work process in its relational dimension, which comprises learning and support to workers ${ }^{(8)}$, providing care of quality, comprehensive and integrated. It is an activity guided by the monitoring of actions $^{(9)}$ and activities of permanent education in health.

Power relations are present in the supervision, since they are present in our society, permeating work relations and other social relations. Here, the power will be considered from the perspective of micro relations, and not only in its negative face of repression, since it also generates the production of knowledge ${ }^{(10)}$.

In face of such theme, we emphasize the need to review the process of subordination and the relations of power-knowledge established in the work routine, which are often seen as natural. Revisiting these relationships can lead to the questioning of how supervision has been carried out, and about new possibilities of acting.

In the literature, we identified publications that define nurses as both instructors and supervisors of the ACS ${ }^{(1,5,11-}$ 12), and reinforce the potentiality of supervision for work qualification, as well as for the relationships between these two actors ${ }^{(11,13-14)}$. These studies address the general supervising done by nurses, however, none of them deals specifically with the supervision of the ACS by nurses.

Considering that supervision has been historically developed by nurses in the daily work in primary care and, as previously stated, that the power-knowledge relations in the process of nursing supervision tend to become natural, it is regarded that the theme the supervision of nurses in relation to ACS in the ESF should be especially investigated, and that this activity should not be analyzed as just another one among the supervisory activities performed by nurses within primary care.

Thus, this study was carried out aiming at answering the following question: in the work of nurses, which conceptions are guiding your supervision activities of the ACS, with a view to the change proposal of the care model through the ESF? The objective was analyzing the conceptions of ESF nurses about the supervision of ACS.

\section{METHOD}

This is a qualitative study ${ }^{(15-16)}$ with no perspective of searching for regularities and repetitive patterns, but rather the production of knowledge about the meaning of supervision for those involved, considering the dynamic and procedural nature of reality.

The study was carried out in 14 municipalities belonging to a regional health center in the state of Goiás (Brazil) that consists of 18 counties, comprising about 270,000 users. The choice of the region was due to the prior knowledge of the area and the significant presence of the ESF as the form of assistance organization in the primary care.

The municipalities showed diversity in the organization of health services in primary care, with family health teams working in adapted properties, in more appropriate locations and built specifically for this purpose, teams with urban and rural area coverage, teams with urban operations only, among other aspects.

The inclusion criteria for subjects participating in the study were being an ESF nurse active in one of the surveyed municipalities, and a supervisor of the ACS. Nurses who had the job position of general manager of ESF, but not ACS supervisors were excluded. Thus, 18 subjects were included in the study.

The data were collected through interviews carried out in the period between June and September 2013,
Supervision of Community Health Agents in the Family Health Strategy: the perspective of nurses Silva JS, Fortuna CM, Pereira MJB, Matumoto S, Santana FR, Marciano FM, Silva JB, Ferreira M, Mishima SM 
having as scenario the health units where nurses work, or in a service of the local health network.

The technique used to reach the proposed objective was the interview and a semi-structured script was the instrument for data collection. The script included questions to identify respondents: age, marital status, place of graduation, professional experience and additional training, along with questions related to supervision.

The interviews lasted between 34 minutes to 1 hour and 20 minutes, were audio-recorded and transcribed verbatim. They were also identified by the letter ' $E$ ', followed by an Arabic numeral to ensure anonymity of participants. The numerical classification was random, ranging from 1 to 18 .

The principles of content analysis, thematic category modality, were used to organize the data ${ }^{(15)}$, doing an exhaustive reading and identifying units of meaning and categories.

For the analysis was used the theoretical framework of the work process in health ${ }^{(17)}$ and power ${ }^{(10)}$, and these concepts led to the search for an understanding of the results obtained from the proposed objectives.

After reading and analyzing the data, two thematic categories were identified: Supervision that sees it all and Supervision is participating and working together. These categories emerged from the definitions and speeches of study participants, and revealed the different meanings assumed by the supervision theme in the experience of each individual.

As this is a research involving human subjects, the ethical aspects described in Resolution number 466/2012 of the National Health Council were met. The study was approved by the Research Ethics Committee under Protocol CAAE number 13888613.0.0000.5393.

\section{RESULTS}

Study participants are all female, with three months to eight years of experience in family health and aged between 24 and 55 years. Regarding the type of employment, 10 of the 18 respondents are public employees and the others are on a temporary work contract. A great part of nurses graduated from private educational institutions and concluded a lato sensu post-graduate program in different areas, not only in family health

\section{Supervision that sees it all}

The conception of supervision was revealed as a control exercise with monitoring character, carried out through printed instruments and regular meetings with the ACS. The monitoring attitude of nurses is administered by the municipal management, and this characteristic is expressed both in practice as in the speeches that show the conception of supervision.
The supervision of nurses focuses on the problem situations identified by the ACS in home visits, and in the control of these visits through users' signature, control of clock in/out, among others, which can be noticed by the statements of the subjects:

They report the problems found throughout the day, they get here and talk to me, so there's no [pauses]. I even tried to control the time and everything, drop by the unit in the morning and in the afternoon, but it is too complicated, they don't adhere much. So, to avoid making the relationship complicated, which ends up generating uneasiness, so, it's like this, they get here and pass me the problems (...) to the possible extent, we solve them, right?, or try to help (E15).

(...) and also the control of clock in/out. They clock in and out four times a day, at $7 \mathrm{~h}, 11 \mathrm{~h}, 13 \mathrm{~h}$ and at $17 \mathrm{~h}$. Then, most of the times is ... at those times, the problems are raised and brought to me, and most cases are solved. Right? (E1).

Some statements show that the ACS has difficulties in implementing the guidelines and activities proposed by nurses, which is an expected situation in a relationship of control as this one.

And also because it can create uneasiness with them. Because I even asked them to pass (in the unit) in specific times. It's tough. Even stamping the documents every day, the documents of reports, was terrible. (Laughs) (E15).

I ask, I always ask them to bring it in the end of the afternoon. But not all of them deliver it. The person of the microregion 2, she always delivers it in the end of the week. And she is the least productive. (...) Yes, I supervise them, I coordinate the whole team, but I do not have autonomy to warn them, understand? They don't give me that space (E10).

During the interviews, the nurses were requested to define supervision. Among the responses, we obtained the following: actions for controlling workers, and team actions that provide support and monitor the work. However, during conversations about the description of how the supervision was carried out, it became clear that this activity is understood rather as control than with a cooperative aspect. The difficulty was noticed in defining the term, and sometimes respondents used examples of their routine to get to an answer; there was also a respondent who reported not knowing how the supervision should be done.

Supervision? Is knowing what health workers do, if they are going to the houses, how are the visits, if it is a visit or if they're going there only to get a signature, if it's a visit in which they're going inside the house to know how things are, if people need anything, how is the guidance and if they are working on prevention (E12).

No. Actually, I don't know how to do it. (laughs) (...) And also because it can create uneasiness with them (...) I think it's a follow-up. Like, closer, you know? A follow-up sometimes also with records of this monitoring (E15). 
In the interviews, we identified reports of the ACS supervision in their sporadic or scheduled accompanied home visits. In one of the reports, the nurse referred to observe how the ACS is received by the family, in cases of complaints from residents of the area covered by the health unit. In another report, the weekly scheduled home visits of nurses with ACS is understood as the only supervisory action carried out.

I come along for many visits; so, once a month I go to the area. Then I can find out if they're doing their job, if they are doing the visits. Oh, it's been a long time since... Long time no see! You haven't been here in a long time I can tell if they're doing the visits or not. And by the complaints in the unit. Because they say like that: $\mathrm{O}$, is there a health agent in XX street? I can know if they're going or not (E12).

It's like this: I organized that every Friday I come along for a visit with the agents, and I'm the only one doing it too (E13)

In most interviews, there are reports of complaints from the population about the work of the ACS. This is a way to alert nurses on the need to carry out a supervision of monitoring in the microareas, called in loco supervision or audit by them.

\begin{abstract}
And we do this follow-up one by one. And since l've been here, it's been two years that I'm here, in these two years I could do three in loco supervisions of each microarea (...) I guess that was it, just three (...) it is my way of supervising them (E16).
\end{abstract}

But I did as if in an interview. I do not know if I did right; for example, from one to ten, for when they give the information, the guidance is good, so I asked the person to rate from one to ten. Oh ... seven, five. Because then, in the end, I made a table of how many points would be good, how many points would be regular or poor (E5)

During the interviews, the nurses showed printed material elaborated by themselves, with the objective of evaluating how the the ACS do their work, with information obtained from the community. This printed material has questions on guidance given by the ACS, estimated duration of home visits, questioning of users about the services offered by the ESF, and other health services existing in the municipalities.

The actions of supervision developed are influenced by the local health management, which possibly results in some dispute between the technical power and the political power of managers.

More specifically, it is for the professionals linked to the unit, right? Then, kind of indirectly, but with a certain pressure from the management, then we do this kind of supervision, and this assessment is based on some issues raised, and is taken to the manager, and it's up to her to make the decisions deemed necessary (E1).
Over these five years I've been observing, I do not even know if ethically, l've, because the supervision [pause] in the previous administration, I had a serious problem here in the last management, because it was a relative, and concealed a bit. Can I talk like that? (E5).

\section{Supervision is participating and working together}

The second analysis category of the interview refers to the actions of supervision as part of the nurses' work, and is based on the monitoring of actions developed by ACS workers and other workers of the family health team. The interviewees understand the importance of supervisory actions as their assignment and emphasize that due to their roles in family health team, nurses are the most accessible workers for the ACS and able to develop such actions.

It is [pause] direct supervision related to the agents and the unit, also because the role of nurses, my role and the other nurse's role, is the supervision and coordination (E1).

I believe the supervision means participating and working together, because I think it's impossible to supervise without participating and without having a feedback of what is being developed. (...) I believe that nurses are in a technical position to help the ACS (E16).

A part of the respondents believes that supervision is an action of support, and also of training and monitoring, reaffirming the cooperative character found in the second category of analysis.

Generally we work on a specific topic according to the indicators; an example, we had high indicators, high rates of leishmaniasis. We thought it would be important to do continuing education activities on this theme. (...) Generally, we have meetings, circles of conversation, that's the kind of work. (...) I never miss the meeting to discuss the microareas problems, because I reckon this is also supervision, is also continuing education (E16).

The supervision of the ACS' work by nurses has another approach based on the monitoring of families by tracking the reports and indicators. In addition to this, there is the organization of work of the ACS, nurses and other team members linked to programmatic health actions.

In the beginning of the month, they get their work schedule and it has the days of meetings, they have to invite the population. Their names will be on the days they will attend the meetings, their names will be written at the meeting that they have to participate, and then, at the end of the month, there is a specific day already on the schedule, when they do the monthly consolidation and we call them. Then they will bring the form $B$, for the monitoring of hypertensive, diabetic, pregnant women, we have a notebook where the agents record their visits, who have they visited, the time of the visit, the day and what they did, and the person's signature. At the end of the notebook, they have the control of children under one year, from two to three years, five years, hypertensive and diabetic, the medication people take, it's (...) (E9).
Supervision of Community Health Agents in the Family Health Strategy: the perspective of nurses Silva JS, Fortuna CM, Pereira MJB, Matumoto S, Santana FR, Marciano FM, Silva JB, Ferreira M, Mishima SM 
But it's like that, I do my visits with community agents per day. On Mondays I go with the agent 1, on Tuesdays with the agent 2, and on Thursdays I go with the agent 3 . As I have 11 agents, I do a rotation for a month. I rotate among them. Then I say to agent 1: Let's see the pregnant women, uncontrolled hypertensives, diabetics, the postpartum women. Then, well, they know where they'll take me (...) (E12).

\section{DISCUSSION}

In the first category, Supervision that sees it all, we see that even in the ESF, another logic should be implemented in the work process, aimed at changing the health care model. The supervision is exercised by nurses primarily for monitoring and control of the work ${ }^{(1,4-5)}$.

The purpose of the supervision is the quality of care provided to users. This qualification of care is guided by the logic of programmatic actions focused on specific groups and disease prevention through the transmission of information.

However, the ESF and the own inclusion of community agents as a connection between the team and the population were made assuming the full attention focused on family relationships ${ }^{(18)}$ and the cycle of life, and not in groups guided by diseases (hypertension, diabetes, family planning, among others). The conception of health and disease that guides the approach to the object of work and the choice of instruments in the work process should consider the determinants and conditions of the process of health and disease ${ }^{(19)}$.

The supervision to the ACS remains guided by a logic of carrying out home visits or not, with the transmission or not of preventive information or issues regarding the already existing diseases, in order to offer consultations and medical procedures, such as collecting preventive exams, vaccines, among other. These findings corroborate other researches on the work of nurses in the $\operatorname{ESF}^{(1,4,6,11)}$.

It is possible to infer that the work process of nurses regarding the supervision of the ACS is guided by the objective that the agents carry out the recommended number of visits and preventive orientation with each individual of every family.

Another point to note is the association of supervision of the ACS when there are problems, which may indicate a correlation between the way of doing and the way of work management. In the biomedical model, health interventions are put into action in the presence of diseases ${ }^{(2)}$, in the same way that supervision is related to moments of dysfunction, constituting a sort of correctional action.

Put another way, the interviews indicate that there was no reinvention of the supervision done by nurses in the ESF. The scenario of practice changed, by including and a new agent under the supervision of nurses, but the traditional logic of work control prevails.
Considering that power is not acquired nor a structure, but linked to a strategic situation ${ }^{(10)}$, the data show an exercise of power in the supervision of the ACS. However, there is resistance from the ACS when not carrying out the proposed activities, with the possibility of allying with other agents who explicitly hold the power.

Still in the first category, in the exercise of supervision that sees it all, and doing it for demanding production at the end of the month, we also found a limitation to such supervision by the municipality manager, who normally are general municipal health secretaries, or heads of municipal departments of health. Such issues were not explicitly addressed by the research participants considering the implications and relations of power-subordination in the work process.

This aspect has not been identified in the literature review on the supervision of nurses to the ACS, and seems to include an important dimension of this practice, because in Brazilian municipalities, the municipal health secretary is a position of trust of the mayor. Health team workers directly linked to municipalities, especially to the ACS, for their strategic work with families, are often considered political parties allies or non-allied.

A study ${ }^{(20)}$ shows that the interference of political parties, and the political interference at the level of municipalities are constantly present in the routine of the family health teams. These issues cause difficulties for the work process and for the relationships between the manager and workers. Another important issue addressed in the study is the precarious employment relation used as an instrument of political control over the ESF.

In the process of implementing the family health teams in Brazil, many workers, especially the ACS, were recruited and hired through nomination and a selection process. The public concourse is a recent requirement, even though this has been a demand since the Federal Constitution. This process leaves margins for the electoral and political use of health and its workers, which undoubtedly interferes in the processes of supervising the work.

This aspect brings uncertainty to the supervisory work of nurses, who create strategies not always explicit to deal with it. One strategy is to talk and convince the municipality manager about how the work of ACS should be done. Another way is by not creating uneasiness at work, because one does not known which political party will be in the administration of the next electoral mandate. Thus, nurses carry out the supervision mainly aimed at controlling the work of ACS, but with limits of power to do it. The question is: in case a nurse comes across the work improperly done by an ACS with kinship relations and political-partisan links with the municipality manager, how should he/she carry out the supervision? Such question becomes evident in the fragment: in the previous administration, I had a serious problem here in the last management, because it was relative, and concealed a bit (E5). 
Data on the terms of the employment contract of nurses also indicate that approximately $50 \%$ of the interviewees have temporary employment contracts, which may influence the way that they operate at work $^{(21-22)}$ and supervise the ACS.

In the literature there is a study ${ }^{(22)}$ that showed, in 2004, the existence of 15 types of employment contracts in the Unified Health System (Sistema Único de Saúde ) with precarious employment relationships. Being hired through nomination or a public concourse certainly interferes in the management, supervision and may even interfere with the care provided.

Still in the first category is the verbalization by nurses of home visits with families as a tool for supervising the ACS. The nurses report using information from the families about whether there had been visits of the ACS or not, in order to assess their work through a score. There were no reports of team meetings nor discussions with families about the purpose of the visits and the characteristics of the work of the ACS.

It seems that nurses start from the premise that families should evaluate the work of the ACS considering their own conceptions, which are basically: making home visits or not, passing information or not. This relationship with the population teaches and reaffirms a reduction of what the work of the ACS and the nurses could constitute: one visits and informs, and the other controls.

In this sense, the supervision of nurses to ACS could produce a kind of ripple effect: the nurse controls the work of ACS, who reproduce this monitoring in the homes and families.

We can say that in this exercise of power there is a production of reality; power is not something negative, but has productions: it produces logic and truths ${ }^{(10)}$ that are naturalized as part of the health work and part of the work of nurses and the ACS, without coordination with the primary aim of the work process.

In order to carry out the supervision, the nurses create instruments to be completed by the ACS; some with a signature of a member of the visited family, others using the strategy of clock in and clock out several times a day. These instruments alone do not ensure that work is done, may reaffirm productivity in itself as a purpose of work, and instigate the invention of other forms of being off work: the meaning of work, its limits, its difficulties and its importance are no longer the agenda in the circles of talk of the team.

In the second category were grouped fragments that articulate the supervision of a more educational dimension with monitoring of the work and feedback between the actors. We can say that such prospects approach the contemporary dimensions of work management in general, called neo taylorism ${ }^{(23)}$.
Although they still show differences with respect to the simple exercise of work control for increased productivity, the actors are interested in producing more harmonic environments, more horizontal relations, but with the same purpose: controlling productivity and the autonomy of workers.

Thus, the question put by classical authors of Brazilian public health remains unanswered: how to combine freedom with control or autonomous work with responsibility ${ }^{(24)}$ ?

The supervision doing together can be a first step toward other forms of supervision, but it requires reflections from nurses and the health care team regarding the cohesive articulation of this instrument - supervision - with the purpose of work, the adopted concept of health-disease, as well as of management and care.

The data indicate that nurses assume for themselves the job of supervising the ACS, and consider it part of their duties. Although difficult, this activity certainly empowers. One respondent questioned whether this should be an assignment of the nurse or of the whole team. The supervision of ACS by the entire team could be proposed simply to share the difficulty of controlling work with other workers, or direct the work in the ESF towards teamwork. In this sense, it would be possible to think the work collectively. Thus, work management is everyone's job, since all govern ${ }^{(25)}$.

It is noted that the discussion and experience of comanagement practice ${ }^{(23,26)}$, although recommended in the National Humanization Policy, are still far from the health services.

Some interviews interconnect the supervision and the actions of permanent and continuing education. Only a minority of respondents related such actions with supervision, showing that the educational character of supervision for the qualification of health care is not the predominant perspective for these workers.

\section{CONCLUSION}

In this article, we aimed at identifying the concepts that guide the work of supervising the ACS held by the ESF nurses, as well as verifying if the activity is consistent with the prerogatives of changes of the care model proposed in the current legislation. A highlight is the need for supervisory actions guided by horizontal relationships, as well as by support and learning, aligned to the guidelines of the National Policy of Primary Care with the view of developing the worker's critical thinking.

It was found that this latter conception of supervision is not yet observed in the routine of the ESF, where traditional logic is maintained, with emphasis on work control and impacted by influences of political parties. The work
Supervision of Community Health Agents in the Family Health Strategy: the perspective of nurses Silva JS, Fortuna CM, Pereira MJB, Matumoto S, Santana FR, Marciano FM, Silva JB, Ferreira M, Mishima SM 
of nurses is strongly guided by programmatic actions, a logic that should be overcome by ESF. Supervision is understood as control of production, monitoring and discipline. In the interviews, it was possible to find nurses that perceive supervision close to a relational perspective, which includes actions of learning and follow-up, but this was not evident in a dominant form.

\section{REFERENCES}

1. Coelho MMF, Miranda KCL, Bezerra STF, Cabral STF, Leite R. Supervisão como tecnologia para a melhoria da atenção básica à saúde. Rev RENE. 2012;13(3):704-11.

2. Matumoto S, Fortuna CM, Mishima SM, Pereira MJB, Domingos NAM. Supervisão de equipes no Programa de Saúde da Família: reflexões acerca do desafio da produção de cuidados. Interface Comun Saúde Educ. 2005;9(16):9-24.

3. Oliveira VC, Gallardo PS, Gomes TS, Passos LMR, Pinto IC. Supervisão de enfermagem em sala de vacina: a percepção do enfermeiro. Texto Contexto Enferm. 2013;22(4):1015-21.

4. Carvalho JFS, Chaves LDP. Supervisão de enfermagem no contexto hospitalar: uma revisão integrativa. Rev Eletr Enferm [Internet]. 2011 [citado 2014 fev. 12];13(3):546-53. Disponível em: http://www.fen.ufg.br/fen_revista/v13/n3/pdf/v13n3a21.pdf

5. Ayres JA, Berti AW, Spiri WC. Opinião e conhecimento do enfermeiro supervisor sobre sua atividade. REME Rev Min Enferm. 2007;11(4):407-13.

6. Gorry C. Primary care forward: raising the profile of Cuba's nursing profession. MEDICC Rev. 2013;15(2):5-9.

7. Rocha SMM, Almeida MCP. O processo de trabalho da enfermagem em saúde coleti-va e a interdisciplinaridade. Rev Latino Am Enfermagem. 2000;8(6):96-101.

8. Brasil. Ministério da Saúde. Portaria n. 2488, de 21 de outubro de 2011. Aprova a Política Nacional de Atenção Básica, para a Estratégia Saúde da Família (ESF) e o Pro-grama de Agentes Comunitários de Saúde (PACS) [Internet]. Brasília; 2011 [citado 2014 fev. 12]. Disponível em: http://bvsms.saude.gov.br/ bvs/saudelegis/gm/2011/prt2488_21_10_2011.html

9. Araújo MBS, Rocha PM. Trabalho em equipe: um desafio para a consolidação da estratégia de saúde da família. Ciênc Saúde Coletiva. 2007;12(2):455-64.

10. Foucault M. Microfísica do poder. 25a ed. São Paulo: Graal; 2012.

11. Kawata LS, Mishima SM, Chiarelli MQ, Pereira MJB, Matumoto S, Fortuna CM. At-tributes mobilized by nurses in family health: reaching performances when developing managerial competence. Rev Esc Enferm USP. 2011;45(2):349-55.
The actions of supervision of the ACS developed by the ESF nurses must be revised to be consistent with the proposed changes in the model of care, seeking to expand the views and knowledge of the ACS and the served population, which can strengthen the relationships and teamwork and the denaturalization of power relations at work.

12. Souza MG, Mandu ENT, Elias AN. Percepções de enfermeiros sobre seu trabalho na Estratégia Saúde da Família. Texto Contexto Enferm. 2013;22(3):772-9.

13. Lanzoni GMM, Meireles BHS. Liderança do enfermeiro: elemento interveniente na rede de relações dos Agentes Comunitários de Saúde. Rev Bras Enferm. 2013;66(4):557-63.

14. Costa SM, Araújo FF, Martins LV, Nobre LLR, Araújo FM, Rodrigues CAQ. Agente Comunitário de Saúde: elemento nuclear das ações em saúde. Ciênc Saúde Coletiva. 2013;18(7):2147-56.

15. Minayo MCS. O desafio do conhecimento: pesquisa qualitativa em saúde. 9ạ ed. São Paulo: Hucitec; 2006.

16. Triviños ANS. Introdução à pesquisa em ciências sociais: a pesquisa qualitativa em educação: o positivismo, a fenomenologia, o marxismo. São Paulo: Atlas; 2007.

17. Gonçalves RBM. Práticas de saúde: processos de trabalho e necessidades. São Paulo: CEFOR; 1992.

18. Pinto RM, Silva SB, Soriano R. Community health workers in Brazil's Unified Health System: a framework of their praxis and contributions to patient health behaviors. Soc Sci Med. 2012;74(6):940-7.

19. Sant'Anna CF, Cézar-Vaz MR, Cardoso LS, Erdmann AL, Soares JFS. Determinantes sociais de saúde: características da comunidade e trabalho das enfermeiras na saúde da família. Rev Gaúcha Enferm. 2010;31(1):92-9.

20. Medeiros CRG, Junqueira AGW, Schwingel G, Carreno I, Jungles LAP, Saldanha OMFL. A rotatividade de enfermeiros e médicos: um impasse na implementação da Estratégia de Saúde da Família. Ciênc Saúde Coletiva. 2010;15 Supl. 1:1521-31.

21. Silveira DS, Facchini LA, Siqueira FV, Piccini RX, Tomasi E, Thumé $E$, et al. Gestão do trabalho, da educação, da informação e comunicação na atenção básica à saúde de municípios das regiões Sul e Nordeste do Brasil. Cad Saúde Pública. 2010;26(9):1714-26.

22. Nogueira RP. Estabilidade e flexibilidade: tensão de base nas novas políticas de recursoshumanos em saúde. Divulg Saúde Debate. 1999;(14):18-22. 
23. Campos GWS. Um método de análise e cogestão de coletivos. 3a ed. São Paulo: Hucitec; 2007.

24. Campos GWS. Subjetividade e administração de pessoal: considerações sobre modos de gerenciar o trabalho em equipes de saúde. In: Merhy EE, Onocko R, editores. Agir em saúde: um desafio para o público. São Paulo: Hucitec; 2007. p. 229-66.
25. Merhy EE. Em busca do tempo perdido: a micropolítica do trabalho vivo em saúde. In: Merhy EE, Onocko R, editores. Agir em saúde: um desafio para o público. São Paulo: Hucitec; 2007. p. 71-112

26. Marin MJS, Storniolo LV, Moravcik MY. Humanization of care from the perspective of the Family Health Strategy teams in a city in the Interior of São Paulo, Brazil. Rev Latino Am Enfermagem. 2010;18(4):763-9.

\section{Financial support}

Conselho Nacional de Desenvolvimento Científico e Tecnológico - CNPq. Process number 130197/2012-2 and

Process number 311219/2013-6 